\title{
The Balkans as a Hierarchical Market Economy
}

\author{
Edgar J. SAUCEDO-ACOSTA \\ Economics and Social Research Institute, University of Veracruz, Mexico, \\ esaucedo@uv.mx \\ Doris Yazmin SALINAS AGUILAR \\ Economics and Social Research Institute, University of Veracruz, Mexico, \\ dyazminsalinas@gmail.com \\ Jesús DÍAZ PEDROZA \\ Department of Economics, Metropolitan Autonomous University-Iztapalapa, Mexico, \\ jdp@xanum.uam.mx
}

\begin{abstract}
The Balkan capitalism has been classified as: Coordinated, Liberal, Mediterranean and as a version of the region itself. Nevertheless, such classifications do not consider the hierarchical economy levels of the region, which for developing countries is a very important feature. Schneider classified the Latin American economies as hierarchical and points out such classification could be applied to middle-income economies of other regions of the world. The aim of the paper is to show that Balkan economies can be considered as hierarchical. To do that, we estimate a Hierarchical Economy index to both regions (Balkans and Latin America). Besides, we test the relationship between inequality and the hierarchical levels (suggested by Schneider). Results show Balkan economies can be classified as hierarchical, because their hierarchical economy indexes are similar to those presented by Latin American economies and there is a negative relationship between inequality and the hierarchical levels among middle-income countries.
\end{abstract}

Keywords: hierarchical market economy; Balkans; Latin America; lack of competitiveness; inequality;

JEL Codes: O52; O15; P50;

DOI: http://doi.org/10.24818/ejis.2019.06

\section{Introduction}

Balkan countries gained their independence after the collapse of communist regimes across the region. The economies of these countries underwent an enormous economic transformation. In addition, Balkan economies changed their economic systems, from socialism to capitalism after the fall of the Berlin Wall. Nevertheless, these economies have taken different pathways in the following aspects: integration with the European Union, privatisation and trade liberation processes. The above aspects and structural changes $(90 \mathrm{~s}$ and 2000s) affected trajectories taken by Balkan economies and the variety of capitalism chosen.

Bartlett (2007) and Knell and Srholec (2007) found out that Balkan countries were located in some extreme of Hall and Soskice (2001) classification, i.e., Liberal Market Economies (LME) and Coordinated Market Economies (CME). Bartlett (2007) point outs some countries of above region have a Mediterranean capitalism (Amable 2016 classification), 
and even other authors emphasize such region has its own variety of capitalism (Farkas, 2011). However, such classifications do not include hierarchical economy levels, with the following characteristics: diversified business group with low levels of competitiveness, low union density and low skills of workers.

Schneider (2009) point outs institutions in middle-income countries are not constraints as in high-income countries. Instead of institutions, organizations are key players in the behaviour of firms. Such author highlights that high level of inequality as a result of negative institutional complementarities among organizations. Latin America has the highest levels of inequality in the world, for this reason Schneider studied the region and found it can be considered as a Hierarchical Market Economy (HME).

The aim of the paper is to show that the Balkan region can be considered as a HME that Schneider (2009) used to characterize the Latin American region, but he highlighted that could be applied to others regions of the world. To do that, we use with the HMEs organizations: Diversified business group (and multinationals), atomized labour relations and low labour skills. To each organization were used indicators to do comparative analysis between Balkan region and Latin America, besides we include CMEs and LMEs as a benchmark. Additionally, a Hierarchical Economy index (HEI) and three sub-indexes were built: lack of competitiveness, low skills and informal economy. The HEI was applied to middle-income economies in the world, in order to locate the Balkan economies in the international context. Results show lack of competitiveness and high level of informal economy for Balkan economies, besides the HEI of both regions (Balkans and Latin America) are quite similar. There is a negative relationship between the inequality and the HEI among the middle-income countries, as have been suggested by Schneider (2009).

We classified the Balkan region as a HME, which can be considered as original. Such region differs from Latin America but shares several similarities. The findings show that the Balkan region can be considered as a HME, although its levels of inequality are lower than those of Latin America but have increased since the 2000s.

The methodology used helps to classify the regions with specific variables based on theoretical considerations (Varieties of capitalism theory) and benchmarks (CMEs, LMEs and HMEs). Therefore, we consider this methodology could be applied in other countries.

\section{Literature Review}

\subsection{Varieties of capitalism}

Hall and Soskice (2001) proposed a new analysis centred in how the firm solve their coordination problems, and in that way, they established different varieties of capitalism. Those authors divide development countries in LMEs and CMEs.

In LMEs, firms solve their coordination problems through formal institutions, i.e., with hierarchies and explicit legal contacts. In those economies, competition relationships among firms are established and the bargain with unions take place in factories, besides radical innovations are generated in high technology sectors. In CMEs, firms solve their coordination problems through informal institutions, with long run trust relationship among employers and employees and there is a permanent monitoring that allows for faster decision making. Unions are involved in the decision making of the firm, besides there are incremental innovations. United States is the most representative case of the LMEs and Germany is the most representative case of CMEs. 
Amable (2003) extended the analysis to five kinds of economics: market-based economies (as LME of Hall and Soskice), social democratic model, Asiatic capitalism, European continental capitalism and Mediterranean (South-European) capitalism. Amble's classification went beyond of Hall and Soskice's classification, but still was applied to development countries. The Mediterranean capitalism includes countries such as Greece, Italy, Spain, Portugal and Spain. Greece was considered as Mediterranean capitalism, due to its lack competitiveness, low level of innovation, high employment protection and low social protection (Amable, 2016).

Schneider (2009) built a new model that includes Latin America, but also can be applied to other regions of the world (Southeast Asia, Turkey and South Africa, etc.). This author considers that legal institutions in developing countries do not work as they do in developed countries, because laws are not the main driver of the firm's behaviour and there are negative institutional complementarities among organizations. Schneider (2009) sees Latin America as a HME in which organizations have a more important role than institutions. Hierarchical capitalism generates inequality, because organizations establish strong links with governments and obtain advantages.

Schneider (2009) proposed the following organizations: Diversified business groups (and multinationals), low skills and atomized labour relations. Diversified business groups and multinationals are established in monopolies and oligopolies, which allow them to obtain high profits, but reduce incentives to innovate. Therefore, low levels of innovation reduce the possibilities to hiring highly qualified workers, and they have no incentives to invest in themselves. Relations between firms and unions are vertical in HME, because governments prioritize diversified business groups and multinationals instead of unions. Thus, Latin American companies have high profits, while workers have low skills and wages, which increases inequality in the region.

Bizberg and Théret (2015) consider that classifying all Latin America economies as a HME is not the most appropriate, because Latin American countries have established economies that have been influenced by how they came out of the Import Substitution Industrialization model, which was implemented throughout the region in the middle of the last century. According to Bizberg and Théret (2015), at least three types of economies could be found: Capitalism oriented by the state and directed to the domestic market (Brazil), Capitalism regulated by the state and directed to the external market (Chile) and Capitalism deregulated and subordinated to the international market (Mexico).

\subsection{Varieties of capitalism in the Balkans}

Bartlett (2007) found that there are three groups of countries in the Balkans. The first group is composed of Croatia and North Macedonia, which after 1990 these nations began a process of rapid privatization, high employment protection and as a result of the labour market reforms were declining and are evolving towards a classic European Continental Model of Capitalism. The second group comprises Albania and Kosovo, with a significant share of private sector in GDP and high informal economy. In Kosovo, unemployment rates are high, unlike in Albania, but this is explained by Albania's high migration rate, and the proportion of public spending on health and education is low. At first sight, these countries have the characteristics of a LME, but the weakness of their financial system, the high degree of informality and the high dependence on their informal institutions, could consider the region as a type of "Unique Balkan Capitalism". The third group comprises Serbia, Montenegro, and Bosnia and Herzegovina, which have characteristics similar to those of Mediterranean capitalism (Amble's classification). However, these countries have a high 
degree of informal economy, reforms are stagnant, and health and education services are poorly funded.

Lane (2005) defines three clusters of post-communist countries (including the Balkan countries). The first is the modern continental capitalist system and characterizes a group of Central European economies. A second cluster is relatively poor, weakly coordinated, with primary sector exports and with low level of integration into the world economy (characteristics of low-income countries). This group is characterized as an uncoordinated hybrid type of market capitalism. A third cluster has high levels of state control, relatively little privatization and a poorly developed market. Lane (2007) states that these new surviving nations of socialism have begun to create a social system with a capitalist market economy and pluralist civil society, leading to the adoption of a neoliberal model (AngloAmerican type).

Knell and Srholec (2007) classify 15 economies in Eastern Europe, as follows: Belarus, Ukraine, Slovenia, Croatia, Romania, Czech Republic, Uzbekistan as CME and Bulgaria, Georgia, Moldova, Poland, Slovakia, Hungary, Estonia and Russia as LME. These authors carry out an analysis of three institutions: social cohesion, regulation of the labour market, and regulation of business.

Adam et al. (2009) analyse the Eastern European region capitalism based in Estonia and Slovenia, in order to contrast how two former Soviet economies followed different paths and each one was defined as an LME or CME. Its institutional regulations were developed in different ways: global and socioeconomic contexts. These authors point out that Slovenia followed the path of CME and Estonia as LME.

Farkas (2011) uses Amble's classification but includes in its study the new member states of the European, those that arose after the disintegration of the Soviet Union and the globalization process, with the purpose of identifying if such economies share institutional similarities with the old European countries. Farkas takes as a basis the five institutions established in the Amble's classification, and also adds Research \& Development and Innovation. Through a conglomerate data analysis and a multidimensional scaling, Farkas establishes that the Central and Eastern Europe Capitalism (CEEC), which includes some Balkan and post-Communist countries (Greece, Bulgaria, Romania and Slovenia) could be added to the Amble's classification (2003).

Farkas (2011) considers that the main differences between the CEECs and the European continental capitalism economies are: the institutional change induced by the EU membership and the different levels of capital stock. Additionally, CEEC economies have a low level of Research \& Development expenditure, there is an imbalance in foreign trade, low production of patents, their banking financial systems are underdeveloped, multinational companies have an important role in the collection of investment funds and there is a strong presence of foreign banks. In the labour sphere, unemployment rates increased, and some unions subsisted but were limited in their participation.

Mádr and Kouba (2016) established two sub-classifications for eight Balkan countries, the market economies (Bulgaria, Croatia, Montenegro and Romania) and the group of hybrid economies (Albania, Bosnia and Herzegovina, North Macedonia and Serbia). However, these authors note that the Balkan countries, as a whole, have a financial system that is not sufficiently developed and a low level of education. 


\section{Methodology}

The main objective of the paper is to show if the Schneider's classification of HME for Latin America can be applicable to the Balkan region. To achieve this goal, the HEI was constructed, taking into account the lack of competitiveness, the size of the informal economy and the years of schooling, which together represent the elements described by Schneider (2009).

The methodology includes: (a) comparative analysis between Balkan region and Latin America (54 countries), (b) calculation of HEI for middle-income economies (79 countries), and (c) estimation of inequality and HEI relationship (127 countries):

(a) Includes the following countries: 6 LMEs, 10 CMEs, 10 Balkan economies and 18 Latin American economies. Countries considered as CME and LME were included as reference points, following a classification made by Schneider \& Karcher (2010). We used 54 countries for 2007 and 2013.

(b) Includes 79 middle-income countries, for 2007 and 2013, because according to Schneider (2009), only countries with middle-income can be considered as HMEs. The World Bank classification of middle-income countries was used, which gave us a total of 79 countries. Two countries from Latin America (Chile and Uruguay) and 3 from the Balkans (Greece, Slovenia and Croatia) were included, even though these countries were barely above the middle-income.

(c) Includes 127 countries, in order to run a regression between HEI and inequality. We decided to use 127 instead of 79, because the statistical properties of larger surveys, for 2013.

\subsection{Comparative analysis: Balkan region and Latin America}

\subsubsection{Multinationals and Diversified Business Groups}

This sub-index measures the lack of competitiveness, because according to Schneider in the HMEs there are monopolies and oligopolies with low level of competitiveness.

The data was collected from the Global Competitiveness Report of the Word Economic Forum (WEF). The measurement scale for this index is from one to seven, with seven being the maximum score that can be obtained. The original data of each country was converted to a scale of 0 to 100 . The following sub-index was calculated:

$$
L C S_{i t}=100-C I_{i t} \ldots(1)
$$

Where:

$L C S_{t i}=$ lack of competitiveness sub-index

$C i_{t i}=$ competiveness index

$\mathrm{i}=$ country

$\mathrm{t}=$ year

The periods taken into account were 2006-2007 and 2013-2014. For the countries that did not have data of such period, the data of previous or subsequent year was used. 


\subsubsection{Low skills}

According to Schneider (2009), one of the most important characteristics of HMEs is the low skill of workers, which in this case will be measured with the expected years of average schooling of adults over 25 years, which is calculated from the educational attainment levels using the official duration of each level. The information obtained comes from the Human Development Index, published by the United Nations Development Program (UNDP). The years taken into account were 2007 and 2013, and the country with the highest indicator was Australia, with 20.2 of expected years of schooling (average). The low skill sub-index was calculated as follows:

$$
L S S_{i t}=\left(1-\left(\frac{E Y o S_{i t}}{\text { HEYoS }_{i t}}\right)\right) * 100 \ldots
$$

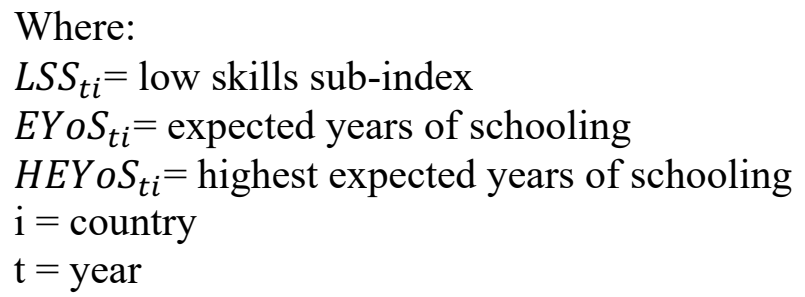

\subsubsection{Atomized labour relations}

An informal economy sub-index was used, because the majority of workers are not unionized in the informal economy, so countries with high levels of informality tend to have atomized labour relations. According to the International Labour Organization (ILO), the informal economy represents the number of workers who are working in the informal sector; this includes informal entrepreneurs or self-employers, domestic workers, and producers of goods for their own final use. Atomized labour relations were constructed from two different databases. The Submerged Economy index, developed by Montenegro et al. (2010), was used as the main source. For nations that did not have data for the 2007, the data for the previous year was taken, and if there was no data for any year, the average for the region was taken into account. The data of such report are up 2007, so the data for 2013 was estimated, based on the growth rates calculated from the data obtained from the ILO database. For the countries that could not calculate the growth rate for having only one data, the average global growth rate was taken from the same database. The data of this variable are in a range from 0 to 100 .

\subsubsection{Gini index}

The Gini index is a synthetic indicator that range from 0 to 1 , where zero is a situation of complete equality and one means total inequality. The Gini index was obtained from the World Development Indicators (World Bank), for the years 2007 and 2013.

\subsection{Estimation of the Hierarchical Economy index}

For the construction of the HEI, the following sub-indexes were used: lack of competitiveness, low skills and informal economy. Based on the methodology used in Saucedo-Acosta and Salinas (2017), the HEI was estimated:

a) For each sub-index its standard deviation from the 79 countries was estimated.

b) To find the weight of each of the sub-index, 0.01 was divided by the standard deviation.

c) Sub-indexes with the highest standard deviations are those with the lowest weightings, with the objective of not affecting countries that have a lot of variability. 
d) Once the weights were obtained, a weighted average was calculated for the index.

e) Finally, we proceeded to add each one of the weighted sub-indexes to conform the HEI by country.

Table 1. Estimation of the weights for the HEI, 2007

\begin{tabular}{|c|c|c|c|}
\hline & $\begin{array}{c}\text { Lack of } \\
\text { competitiveness } \\
\text { sub-index }\end{array}$ & $\begin{array}{c}\text { Low skills } \\
\text { sub-index }\end{array}$ & $\begin{array}{c}\text { Informal economy sub- } \\
\text { index }\end{array}$ \\
\hline Standard deviation (SD) & 9.9375 & 15.1396 & 12.0552 \\
\hline $\mathrm{A}_{\mathrm{i}}=0.01 / \mathrm{SD}$ & 0.0010 & 0.0006 & 0.0008 \\
\hline Weights $=\left(\mathrm{A}_{\mathrm{i}} / \sum_{1}^{3} A i\right)$ & 0.4031 & 0.2646 & 0.3323 \\
\hline
\end{tabular}

Source: own elaboration

Table 1 shows how the weights of the HEI were calculated for the year 2007, higher the value of the standard deviation, lower the weight. For the year 2007, the sub-index of lack of competitiveness had the highest weight, followed by the informal economy sub-index and finally the low-skill sub-index.

Table 2. Estimation of the weights for the HEI, 2013

\begin{tabular}{|c|c|c|c|}
\hline & $\begin{array}{c}\text { Lack of } \\
\text { competitiveness } \\
\text { sub-index }\end{array}$ & $\begin{array}{c}\text { Low skills } \\
\text { sub-index }\end{array}$ & $\begin{array}{c}\text { Informal economy sub- } \\
\text { index }\end{array}$ \\
\hline Standard deviation (SD) & 9.3451 & 14.9278 & 13.7819 \\
\hline $\mathrm{A}_{\mathrm{i}}=0.01 / \mathrm{SD}$ & 0.0011 & 0.0007 & 0.0007 \\
\hline Weights $=\left(\mathrm{A}_{\mathrm{i}} / \sum_{1}^{3} A i\right)$ & 0.4340 & 0.2717 & 0.2943 \\
\hline
\end{tabular}

Source: own elaboration

Table 2 shows the calculation of the weights of the HEI for 2013. As 2007, the lack of competitiveness sub-index had the highest weight, followed by the informal economy subindex and finally the low skills sub-index.

\subsection{Estimation of inequality and HEI relationship}

We estimate the following equation:

Where:

$$
\operatorname{Gini}_{\mathbf{i}}=\alpha+\beta_{1} \mathrm{HEI}_{\mathbf{i}}+\beta_{2} \mathrm{GDPpc}_{\mathbf{i}}+\epsilon_{\mathbf{i}} \ldots \text { (3) }
$$

Gini: Gini index was obtained from the World Development Indicators (World Bank), for the year 2013.

HEI: Hierarchical Economy index for the year 2013, which has been explained in the previous section.

GDPpc: Gross Domestic Product per capita at constant US dollar from World Development Indicators (World Bank), for the year 2013.

$\varepsilon$ : idiosyncratic error term

The required technique was ordinary least squares. In order to avoid heteroscedasticity, we run robust model. 


\section{Results and Discussion}

Balkan countries show a HEI close to that of the Latin American countries, and above CMEs and LMEs (Figure 1). The Latin American countries show a higher rank than Balkan countries, but as a whole they are close in terms of their medians. Balkan countries can be considered as hierarchical, however there are some countries with lower hierarchical level than the rest of the countries in that region, although higher than the CMEs and LMEs.

Figure 1. HEI 2007-2013

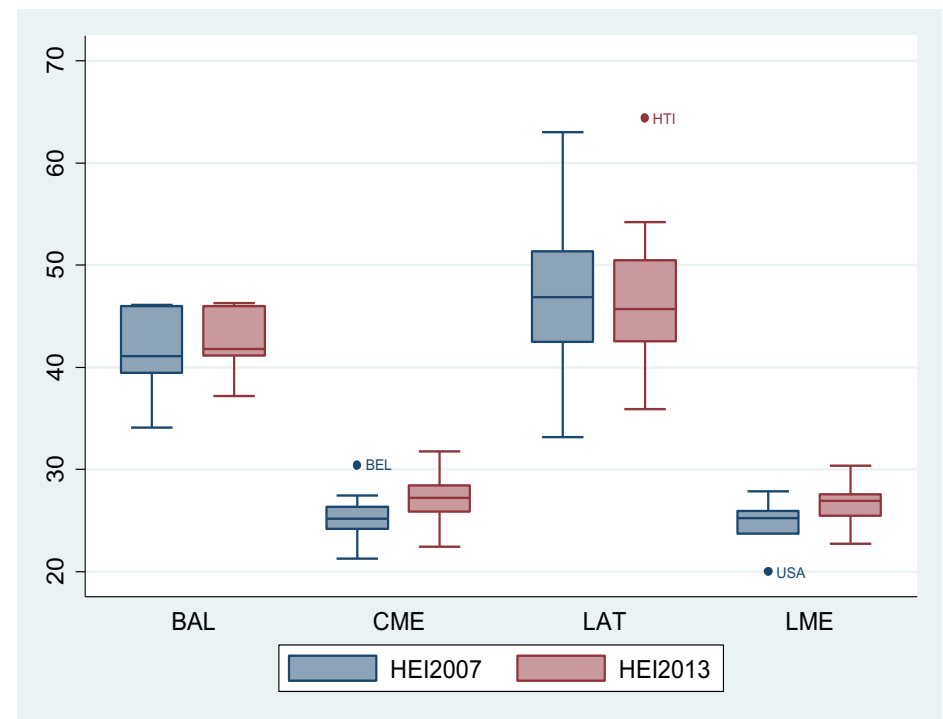

Source: own elaboration with data from WEF, UNDP, Montenegro, Schneider \& Buehn (2010) and ILO

Balkan countries do not have a high level of inequality such as that presented by Latin America, although between 2007 and 2013 there was an increase in this variable (Figure 2). The Gini index shows Balkan countries have a greater dispersion of inequality by country than the CMEs and LMEs and lower than Latin America.

Figure 2. Gini index, 2007-2013

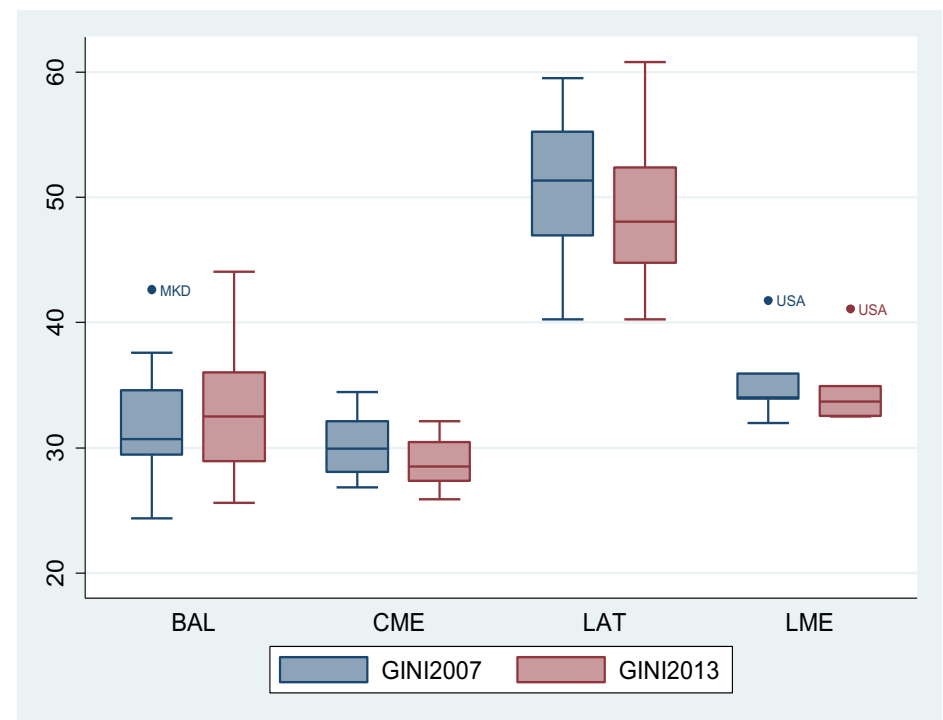

Source: World Bank 
Figure 3 shows Balkan countries have a sub-index of low skills greater than presented by LMEs and CMEs, but below than Latin American region. From 2007 to 2013 there is a reduction of such sub-index, but this reduction is marginal, besides that it is too far to be considered as CME or LME.

Figure 3. Low skills sub-index, 2007-2013

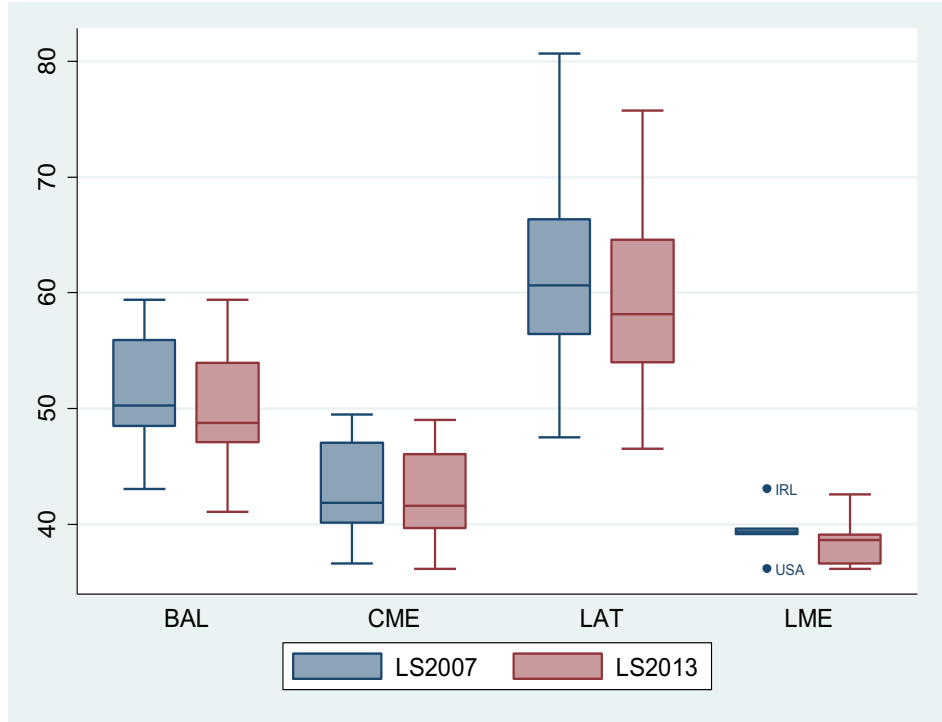

Source: own elaboration with data from UNDP

The informal economy sub-index shows Balkan region can be considered as an HME (Figure 4), because in 2013 such region is at the same level than Latin America. Balkan countries cannot be considered as a CME or LME.

Figure 4. Informal economy sub-index, 2007-2013

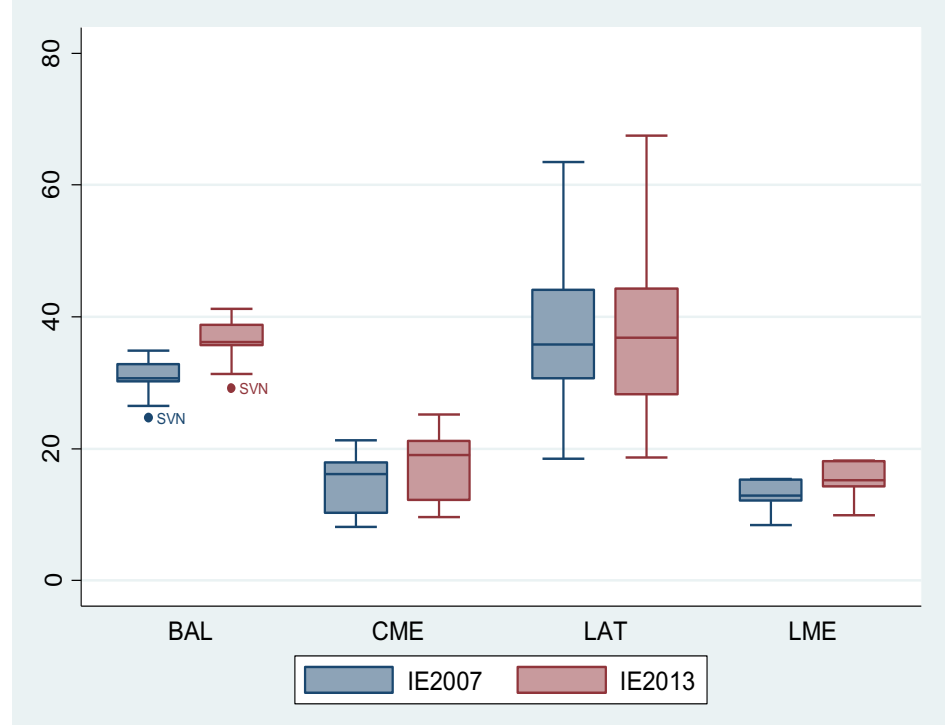

Source: own elaboration with data from Montenegro et al. (2010) and ILO (2018)

Figure 5 shows Balkan region can be considered as an HME, because the lack of competitiveness is very close to the one presented by the Latin American region, and higher than LMEs and CMEs. 
Figure 5. Lack of competitiveness sub-index, 2007-2013

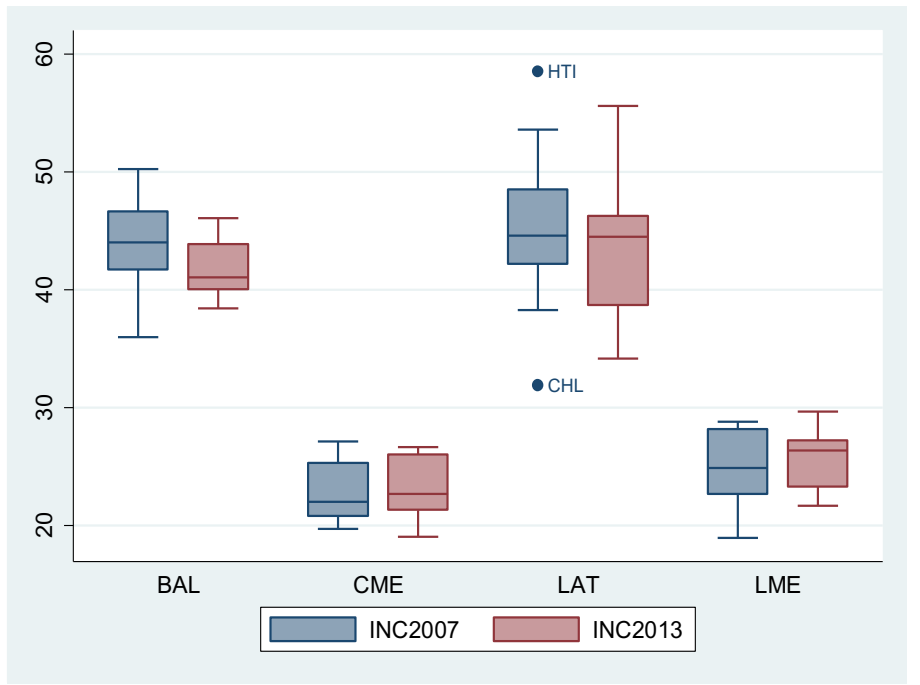

Source: own elaboration with data from WEF

Table 3. HEI of 79 middle-income countries, 2007-2013

\begin{tabular}{|c|c|c|c|c|c|}
\hline Ranking07 & Country & HEI 07 & Ranking13 & Country & HEI 13 \\
\hline 3 & Bolivia & 56.01 & 9 & Honduras & 54.18 \\
\hline 4 & Guatemala & 55.34 & 15 & Nicaragua & 52.46 \\
\hline 7 & Nicaragua & 54.13 & 17 & Bolivia & 51.81 \\
\hline 11 & Honduras & 52.92 & 21 & Guatemala & 51.25 \\
\hline 13 & Peru & 51.74 & 23 & El Salvador & 50.84 \\
\hline 18 & Paraguay & 50.92 & 24 & Peru & 50.16 \\
\hline 21 & El Salvador & 50.39 & 25 & Venezuela & 49.58 \\
\hline 27 & Uruguay & 48.51 & 32 & Paraguay & 48.50 \\
\hline 32 & Brazil & 47.07 & 39 & $\begin{array}{c}\text { Bosnia and } \\
\text { Herzegovina }\end{array}$ & 46.26 \\
\hline 35 & Ecuador & 46.61 & 40 & Colombia & 46.05 \\
\hline 38 & North Macedonia & 46.12 & 41 & North Macedonia & 46.01 \\
\hline 39 & $\begin{array}{l}\text { Bosnia and } \\
\text { Herzegovina }\end{array}$ & 46.08 & 42 & Albania & 45.98 \\
\hline 40 & Albania & 45.98 & 46 & Serbia & 45.03 \\
\hline 42 & Colombia & 45.71 & 53 & Brazil & 44.02 \\
\hline 43 & Venezuela & 45.50 & 57 & Argentina & 42.78 \\
\hline 53 & Panama & 43.25 & 60 & Uruguay & 42.36 \\
\hline 55 & Serbia & 42.71 & 61 & Greece & 42.22 \\
\hline 60 & Bulgaria & 41.65 & 63 & Mexico & 41.39 \\
\hline 62 & Mexico & 41.44 & 64 & Romania & 41.36 \\
\hline 65 & Costa Rica & 40.62 & 65 & Montenegro & 41.30 \\
\hline 66 & Montenegro & 40.56 & 66 & Bulgaria & 41.08 \\
\hline 67 & Argentina & 40.44 & 67 & Croatia & 41.00 \\
\hline 68 & Romania & 40.31 & 68 & Ecuador & 40.98 \\
\hline 70 & Croatia & 39.44 & 70 & Costa Rica & 39.73 \\
\hline 72 & Greece & 38.46 & 71 & Panama & 39.48 \\
\hline 78 & Slovenia & 34.11 & 75 & Slovenia & 37.17 \\
\hline 79 & Chile & 33.16 & 78 & Chile & 35.91 \\
\hline
\end{tabular}

Source: own elaboration with data from WEF, UNDP, ILO (2018) and Montenegro et al. (2010). 
Table 3 shows the HEIs of the Latin American region and Balkan region, of a total of 79 middle-income countries for the years 2007 and 2013.In both years only Central American countries (Guatemala, Nicaragua, Honduras and El Salvador) and some South Americans countries (Bolivia, Peru and Paraguay) present values above 50, which indicates a high level of HEI, in addition to being within the top 25. North Macedonia and Bosnia and Herzegovina have the highest HEIs in the Balkan region.

For 2007, Albania, Serbia, Bulgaria, Montenegro and Romania had a HEI of 40-45, while Greece and Croatia obtained those values in 2013, which is understandable due to the financial crisis that the Greek economy has had in the last decade. For 2007, Slovenia, Greece and Croatia had an HEI below 40, while for 2013 only Slovenia.

Slovenia is the least hierarchical economy in the Balkan region, but with an HEI (2007 and 2013) above Chile, which is one of the countries used by Schneider (2009) as an example of HME in Latin America. Venezuela and Greece have not the highest HEIs of both regions, but they have the highest increases. The above indicates the enormous economic crisis that both countries are experiencing. We considered all variables of equation (3) for the 127 countries for year 2013.

Table 4. Inequality, HEI and GDPpc for 2013:

OLS estimation (robust model)

\begin{tabular}{|c|c|}
\hline \multicolumn{2}{|c|}{ Dependent variable: Gini index (inequality) } \\
\hline Independent variables & Coefficient \\
\hline Constant & $\begin{array}{c}32.58183 \\
(5.56712)^{* * *}\end{array}$ \\
\hline HEI & 0.18053 \\
& $(0.10756)^{*}$ \\
\hline GDPpc & -0.00009 \\
& $(0.00005)^{*}$ \\
\hline $\mathrm{R}^{2}$ & 0.16 \\
\hline Obs. & 127 \\
\hline
\end{tabular}

Note: numbers in the parentheses represent standard errors $*, * *$ and $* * *$ indicate statistical significance at 10,5 and $1 \%$, respectively

Source: own elaboration

Table 4 shows the results of OLS with robust model, and with inequality as dependent variable. The findings suggest, the higher HEI, the higher the effect on inequality. The coefficient of HEI is positive (0.1805) and significant at 10\%. Nevertheless, GDPpc had a negative impact on inequality. The coefficient of GDPpc is negative $(-0.00009)$ and significant at $10 \%$.

\section{Discussion and Conclusions}

The sub-indexes of lack of competitiveness and informal economy show that Balkan countries can be considered as an HME as a whole. In addition, the HEIs of such European region have hierarchical levels very close to the Latin American countries, and they are far from the CMEs and LMEs. In this sense, the countries of the Balkan region cannot be considered as CMEs or LMEs. 
The level of inequality (measured by the Gini index) of most countries in the Balkan region is not high as that in Latin American countries. However, this region shows an increase in inequality, unlike Latin America (and other regions), where there was a reduction from 2000 to 2010 .

Although the Balkan region as a whole can be considered as an HME, there is a high variation among countries regarding their levels of hierarchy. Slovenia has the lowest HEI for 2013 (37.17), while North Macedonia and Bosnia and Herzegovina have the highest levels of HEI (46).

Balkan economies have been classified as LME and CME (Hall \& Soskice's model), Amable's Mediterranean model and a capitalism of the region itself. Our results do not coincide with results of Bartlett (2007) and Knell and Srholec (2007), because such authors classify Balkan countries at some extreme of LMEs or CMEs and Mediterranean capitalism, and we consider the region as HME. We coincide with Farkas (2011), in the sense Balkan region have own economic characteristics which differs from developed economies. Nevertheless, we consider Balkan region as HME and Farkas a new type of capitalism.

The strength and originality of the paper is to classify the Balkan region as an HME, although it differs from the Latin American model, shares several similarities. The weakness of the paper is that we do not include another type of capitalism as benchmark. The Dependent Market Economies (Nölke andVliegenthart, 2009) could be another option for the classification of the region.

If the Balkan region gets even closer to HMEs, at some point its level of inequality will increase considerably, and their Diversified Business Groups will be strengthened. A possible line of research in the future is to analyse the negative complementarities among the 4 organizations that Schneider proposed for HMEs.

\section{References:}

Adam, F., Kristan, P., Tomšič, M. (2009): Varieties of capitalism in Eastern Europe (with special emphasis on Estonia and Slovenia). Communist and Post-Communist Studies 42: 65-81.

Amable, B. (2003): The Diversity of Modern Capitalism. Oxford: Oxford University Press.

Amable, B. (2016): Institutional complementarities in the dynamic comparative analysis of capitalism. Journal of Institutional Economics 12(1): 79-103.

Bartlett, W. (2007). The Western Balkans. In: Lane, D. and Myant, M. (eds): Varieties of Capitalism in Post-Communist Countries. London: Palgrave Macmillan, 201-218.

Bizberg, I., Théret, B. (2015): Introducción. In: Bizberg, I. (ed.) Variedades del capitalismo en América Latina: los casos de México, Argentina y Chile, México. México: El Colegio de México, 11- 40.

Farkas, B. (2011): The Central and Eastern European Model of Capitalism. Post-Communist Economies 23(1): 15-34.

Hall, P., Soskice, D. (2001): Introduction. In: Hall, P. and Soskice, D. (eds): Varieties of Capitalism. The Institutional Foundations of Comparative Advantage. Oxford: Oxford University Press, 1-68.

International Labour Organization. (2018): ILOSTAT. Available at: https://ilostat.ilo.org/

Knell, M., Srholec, M. (2007): Diverging Pathways in Central and Eastern Europe. In: Lane, D. and Myant, M. (eds): Varieties of Capitalism in Post-Communist Countries. London: Palgrave Macmillan, 40-62.

Lane, D. (2005): Emerging Varieties of Capitalism in Former State Socialist Societies.

Competition and Change 9(3): 227-247. 
Lane, D. (2007): Post-State Socialism: A Diversity of Capitalisms? In: Lane, D. and Myant, M. (eds): Varieties of Capitalism in Post-Communist Countries. London: Palgrave Macmillan, 13-39.

Mádr, M., Kouba, L. (2016): Diversity of capitalism in the European post-socialist economies: the Balkan states at a crossroads. Scientific Papers of the University of Pardubice 23 (36): 152-163.

Nölke, A., Vliegenthart, A. (2009): Enlarging the Varieties of Capitalism: The Emergence of Dependent Market Economies in East Central Europe. World Politics 61(4): 670-702.

Montenegro, C., Schneider, F., Buehn, A. (2010): Shadow Economies All Over the World. Policy Research Working Paper 5356, Washington.

Saucedo-Acosta, E., Salinas, D. (2017): Economías Jerárquicas de Mercado y Desigualdad en América Latina. In: Borrás, F. and Ricárdez, J. (eds): Equidad y Desarrollo Sostenible, Oportunidades y Desafios. Xalapa: CODICE, 59-74.

Schneider, B. (2009): Hierarchical Market Economies and Varieties of Capitalism in Latin America. Journal of Latin American Studies 41(3): 553-575.

Schneider, B., Karcher, S. (2010): Complementarities and continuities in the political economy of labour markets in Latin America. Socio-Economic Review 8(4): 623-651.

United Nations Development Programme. (2018): Human Development Reports. Available at: http://hdr.undp.org/en/data

World Bank (2018): World Development Indicators: Available at:

https://datacatalog.worldbank.org/dataset/world-development-indicators

World Economic Forum (2018): Global Competitiveness Reports. Available at:

https://www.weforum.org/reports/the-global-competitveness-report-2018 